\title{
DEVIL AND ANGEL IN TRANSYLVANiAN PLACE NAMES
}

\author{
JÁNOS M. BÁRTH \\ Eötvös Loránd University, Budapest, Hungary
}

\begin{abstract}
An unrivalled database of historical place-name research is Attila T. Szabó's collection of Transylvanian place names. It has been published in print and online as well and contains some hundred thousand place names. In this paper, I present this database and analyse those names from the above-mentioned collection that were formed with the words ördög (Hungarian for 'devil') and angyal (Hungarian for 'angel'). I review names formed from personal names and those reflecting some kind of popular belief. I describe tales of origin, popular etymologies of such names based on onomastic and ethnographic collections from the 19th-20th centuries. I analyse the geographical distribution of the names, as well as their types and the motivations behind their formation.

Keywords: place name, database, Attila T. Szabó, Transylvania, devil, angel, God.
\end{abstract}

\section{Introduction}

In this paper, the description of the source-material, the database, is much more detailed than usually. As this collection of Transylvanian historical place names has become available online recently (in 2017), I consider it is necessary and useful to present it to a wider international scientific audience. Place names deriving from names of supernatural creatures, though constituting only a small part of this large name database, serve as a great example for the use of the database, while also suiting the topic of the 2017 International Conference on Onomastics Name and Naming (ICONN), "Sacred and Profane in Onomastics".

\section{Attila T. Szabó and his work}

Attila T. Szabó was one of the most prominent 20th-century researchers in Hungarian linguistics. His biography and major works have been studied and published in a stand-alone book by Balassa Iván (Balassa 1996.). On the 100th and 110th anniversary of his birth, several conferences praised his fundamental works (Péntek 2006: 5-12; Bárth 2006; Benő and Szabó 2016). Despite his most famous linguistic work being the Transylvanian Hungarian Historical Thesaurus (Erdélyi Magyar Szótörténeti Tár), his interviews reveal that his favourite field was onomastics. Unfortunately, the collection of Transylvanian historical place names, on which he worked for decades, could not be published during his life due to political reasons. The manuscript collection was finally published between 2001 and 2010 (ETH). 
Attila T. Szabó gave a full account of the accomplishment of such a vast collection of place names in his 1958 article (Szabó 1958: 503-509). He recalled that he had originally planned to collect the place names of his hometown, Dés, with the help of the available archive sources. Getting acquainted with the different documents containing numerous place names provided him with data from diverse parts of Transylvania, thus leading to the idea of a large-scale historical place-name collection, covering the entire territory of Transylvania.

The manuscript collection, assembled throughout decades of work, was eventually heterogeneous in covering the different areas of Transylvania: most historical place names originated from Central Transylvania, less from Székely Land and the south of Transylvania, while the least were collected from border territories.

In the mid 80s, he estimated his collection to amount to 700,000 index cards. Though publishing this ample collection was not possible due to political reasons, he did include some place-name entries in the Transylvanian Hungarian Historical Thesaurus, in which place names provided useful insights into the history of a word.

He envisioned that his collection, arranged according to counties and settlements, could later be completed with other kinds of historical and contemporary data, thus containing various types of information. Nevertheless, it could also be used for monographs dealing with place names in a specific area or a single onomastic phenomenon, as well as for drawing onomastic geographical maps.

\section{Publishing the place-name collection}

After Attila T. Szabós death, the boxes containing the large manuscript collection, with the help of Loránd Benkö and following an adventurous journey, ended up in the National Széchenyi Library in Budapest. Its publishing, lead by Mihály Hajdú, began only in 1999. The index cards were sorted out by Jenő Janitsek, linguistic researcher from Cluj.

Publishing the collection, which took place from 2001 until 2010, made an unprecedentedly redundant mass of data available for researchers in several areas of science. The collection mainly contains data from the 17 th-18th centuries, but some entries from the 15th and 16th centuries can be found as well. Settlement names are outnumbered by microtoponyms such as names of ploughland, hayfields, woods, hills, valleys, brooks, paths and others.

Following Attila T. Szabó's intentions, the collection was published in volumes according to counties. In each volume, settlements of the corresponding county are listed in alphabetical order and the correspondent place-name material is presented chronologically. For easier identification, the Romanian - and if relevant, the German - name of the settlement is also indicated. Historical place names are listed alone, but with the relevant context, often in an inflected form. Most names are part of the Hungarian name system, but many Romanian names appear as well, making the examination of Romanian-Hungarian linguistic contacts possible. 
To keep the orthographical variegation intact, editors had to tackle deciphering numerous special characters and their digital reproduction.

The collection also contains the place names of settlements that have since disappeared; the numerous place names of peripheral areas might conceal a vanished settlement's name. The chronological order of the entries remarkably shows the changes in the place-name system of a settlement throughout time. The collection provides several pieces of information about each place name: most of the time, it mentions the context, the place type and its function (ploughland, pasture, woods etc.), often clarifying ambiguities of interpretation, while possible origins of unknown words are given in parentheses. Entries from a certain source always start with the variations of the settlement name, followed by other place names.

Attila T. Szabó's manuscript collection always contains the source of the data, which were included in the volumes unchanged. Nevertheless, the original sourcematerials can hardly be found now, as some of it might have even been lost since, thus making the manuscript collection irreplaceable and, in some cases, equivalent to the original.

\section{Processing the collection electronically}

From the very beginning of the publishing process of Attila T. Szabós historical place-name collection, an index was considered necessary to help researchers' orientation in this vast amount of data. Even Attila T. Szabó declared that, for the purposes of linguistic research, a dictionary-like processing would be the most appropriate.

During the publishing process, it became obvious that electronic publication can solve this problem, but numerous factors made its realization difficult. Firstly, as the sources contained a vast number of special characters with diacritical signs, a solution that would not limit search possibilities had to be found (for example, when searching for mezö, results should include mezō and mezŏ as well). Secondly, for onomastic research, the demarcation of names seemed necessary (i.e., to define "real" names in context, by means of periphrastic descriptions). Thirdly, the possibility of displaying data on maps was also considered important.

With these aims in mind, between 2006 and 2011 (supported by NKFP and OTKA grants), in the Geolinguistic Laboratory (geolingua.elte.hu), with the help of a software developed by Domokos Vékás and Fruzsina Sára Vargha, called Olló ('Scissors'), we managed to create a database in which one could search among the place names and display results on a map. Its undisputable benefits for onomastic research - mainly onomastic geography - are discussed in several papers (Bárth 2011).

Despite its significant achievements, unfortunately (having the grants exhausted) it stayed offline - only scientific results (e.g. maps of different onomastic phenomena) were published online. Meanwhile, the extremely fast development of information science and the internet made me rethink the fundamentals of online publishing and, thanks to an NKA grant in 2016, it became possible to build a new, up-to-date name database (eha.elte.hu). 
Using the original text files, characters were standardized without compromising letter accuracy (examples for the diversity of diacritical signs: $\dot{a} a ̈ a$ a a a $\dot{a}^{\prime} c^{\prime} d \ddot{e} \ddot{e} e \ddot{e}$

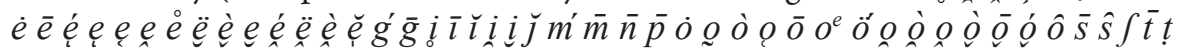
$t^{\prime} T \dot{u} \bar{u} u^{e} \ddot{u} u$ u $\ddot{u} \ddot{u} \bar{v} v^{\prime} \dot{v} V \dot{w} \not{w} \ddot{w} \bar{y} \bar{y} \ddot{y} \ddot{y}^{\prime} \dot{y} y^{\prime} \tilde{y} \tilde{y} z^{\prime} z$ z). With the standard Unicode encoding system, the aim was to correctly display all historical letters and diacritical signs in every online platform, without limiting search possibilities.

The original text files were transformed into tables with the new structure County/Settlement/Year/Source/Entry/Place type attributes. Then, the coordinates of some 2000 settlements were assigned (even the location of since disappeared settlements was identified where possible). The different name variations and foreign names of the settlements were also added. Thus, a database of approximately 350,000 lines has been created. In the Entry field, place names are not demarcated - these are rather descriptions of places, often including several place names. This means that one cannot find a list of nominative stems of place names as such, but with the help of the search engine, any letter combination, word, name or name structure can be found, together with its chronological, settlement, type attributes and its context. With the help of the coordinates, one can produce a map showing the locations of occurrences of the given linguistic form. For this purpose, the popular and incredibly user-friendly Google Maps has been chosen. These maps will hopefully show a number of interesting regional linguistic differences through historical name data. In addition to the Hungarian version, the site is also available in English and Romanian.

There are several searching options in the database: there is a general search field, where you can search in the entire database, and there are search fields above each column, where you can filter that specific column. You can search any names, words or letter combinations. You can filter the database or the search results for any given denotatum type, year, county etc. Time periods can be given as from-to relation as well.

Results can be displayed on an interactive Google Map. By clicking on the pins, pop-up windows will appear, showing the name of the settlement and the entry itself it will list all the entries of the given settlement. Results can also be saved and exported to an Excel file. Records include the coordinates, making it possible to create new maps (for example in Google My Maps application).

The collection contains extremely valuable data due to Transylvania's stormy history and the fact that we do not have a comprehensive contemporary place-name collection from this area, with many place names having disappeared since then.

\section{Devil and angel in Transylvanian place names}

The occurrence of names of supernatural creatures in place names is quite common. They appear all around the Hungarian language area (Thész 2000), as well as in other languages. Hungarian theoretical literature claims that such names result from metaphoric name formation (Hoffmann 1993: 127-133). Most of the time, these names are based on the shape of the specified place - the name giver associates peculiar shapes with supernatural creatures (e.g. Ördögágya 'devil’s bed' describes a rock). 
There are several such names among Hungarian place names of the Middle Ages: Ördögsára 'devil's mud' (1075/1217), Ördögbarázdája 'devil's furrow' (1270), Ördögkútja 'devil's well' (1342), Ördög-kő 'devil's stone' (1416), providing ethnography with proofs for the early existence of popular beliefs and legends (Balassa and Ortutay 1979: 518-519).

Examples from bilingual areas are also interesting: a mountain in Tatra is called Ördög lakodalma 'devil's wedding' in Hungarian, but the Slovak name Čertova Svadba also refers to a popular belief that in rough, snow-stormy weather, one can see the devil celebrating his wedding.

Though you can find names of other supernatural creatures as well (Tündérjuk 'fairy's hole', Sátánkút 'Satan's well'), it is definitely the word ördög 'devil' which appears the most frequently in place names.

Even the word angyal 'angel' figures only occasionally in this huge database, and even these entries are mostly transformed from personal names or through folk etymology. For example, the settlement name Angyalos ('angel' $+-s$ derivative adjective, Angheluş in Romanian), originates from a personal name without a formant, with a Hungarian name giver. The original personal name (1213/1555: Angelus) is derived from Church Latin and its etymology is the same as that of the noun 'angel'. Still, the name has led to several folk etymologies: 1 . the church used to be dedicated to Saint Michael or Saint George, and the village was named after these martial angels; 2 . a fairy, the daughter of the prince of giants, lived there and became an angel; 3. the birch forest next to the village is so beautifully white, like angels' clothes (Bölcskei, Havas and Slíz 2008: 11-12).

The variants Anygyalhegye or Zanygyalhegye of the place name of Egeres settlement have undergone a very interesting transformation. As the name literally consists of 'angel' + 'hill' + possession suffix, everyone construes it as a composition of 'angel' and 'hill', while the version that starts with $Z$ is interpreted as if it has mistakenly remained there from the Hungarian definite article $a z$ 'the.' Nonetheless, the word actually comes from the Hungarian first-name counterpart of Andrew. Its diminutive, Anda, was understood by the Romanian speaking people as Zanda. Then, when it was taken back by the Hungarians, they tried to give it a meaning - 'angel'. This evolution can clearly be seen in the numerous historical data beginning with Ant-, And-, while angyal is absent from the entries (Szabó 1945: 111-112).

The place name Anygyaltér 'angel's place' (collected only in 1938) is probably the only place name in Transylvania which actually comes from the meaning 'angel'. The 20th-century folk explanation claims it is a place that is never muddy and weddingguests always have a dance there.

On the other hand, the word ördög 'devil' appears frequently in Transylvanian place names, in some 400 entries and name variations of 124 objects, from all periods in the database. It is sometimes present in dialectal variants, ördöng or ördöngös, which can refer to the devil itself, but also someone possessed by the devil (devilish in English has a similar meaning). The geographical distribution is shown in Figure 1. 
JáNos M. BÁRTH

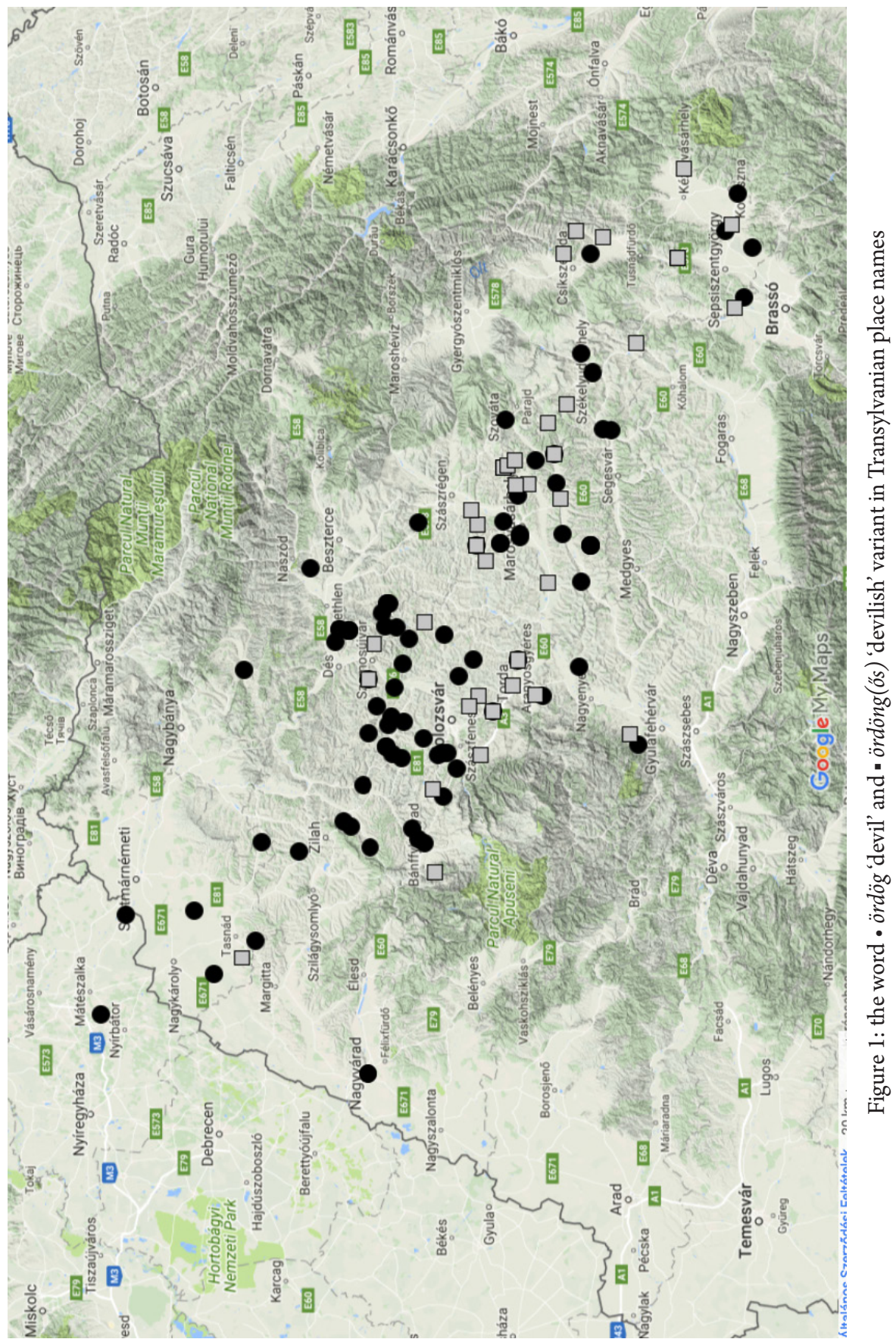


Most names have two constituents expressing a genitive/possessive relation: Ördög árka 'devil's ditch', Ördög pataka 'devil's brook', Ördög halma 'devil's small hill'. There is only one name with a single constituent, but the historical data does not show unambiguously if it was used in speech as Ördög or Ördöghegy.

Most names certainly describe some kind of special, peculiar, frightening or unpleasant place: Ördög lyuk 'devil's hole', Ördögök tava 'devils' lake' (folk etymology says that devils drink from this lake), Ördögsziget 'devil's island', or the very common and suggestive Ördög orra 'devil's nose', often describing cliffs.

Place names transformed from personal names also occur, but to a much smaller extent: Ördög Pál erdeje 'Pál Ördög's forest' > Ördögök erdeje 'devils' forest'.

In bilingual areas, the Romanian versions can also be found, either in the form of name borrowing (e.g. Ördögàjja 'devil's bottom' Urdigọia) or as translations (e.g. Ördögárka 'devil's ditch’ Pârâul Dracului).

\section{The word isten 'God' in Transylvanian place names}

Analysing the occurrences of the word isten 'God' in place names foregrounds interesting results. While ördög, indicating the Satan of Christianity and the evil spirit of popular belief at the same time, is commonly and often used in Transylvanian place names, isten appears in much fewer names (112) within a much narrower territory (Isten kassa 'God's basket', Isten pataka 'God's brook', Isten tövisse 'God's forest', Isten tava 'God's lake' etc.). Geographical distribution is shown in Figure 2.

What can the examination of the geographical distribution of different name types show us? This example illustrates well that place names with the word isten are completely missing from the south of Transylvania and the historical territory of Székely Land. Taking the cultural-social history of the settlements into consideration will bring us to another important aspect: the Hungarian population of these settlements are traditionally Protestant, of Reformed faith. This means that general conventions and terminology of religion practices have a great impact on name-giving. 


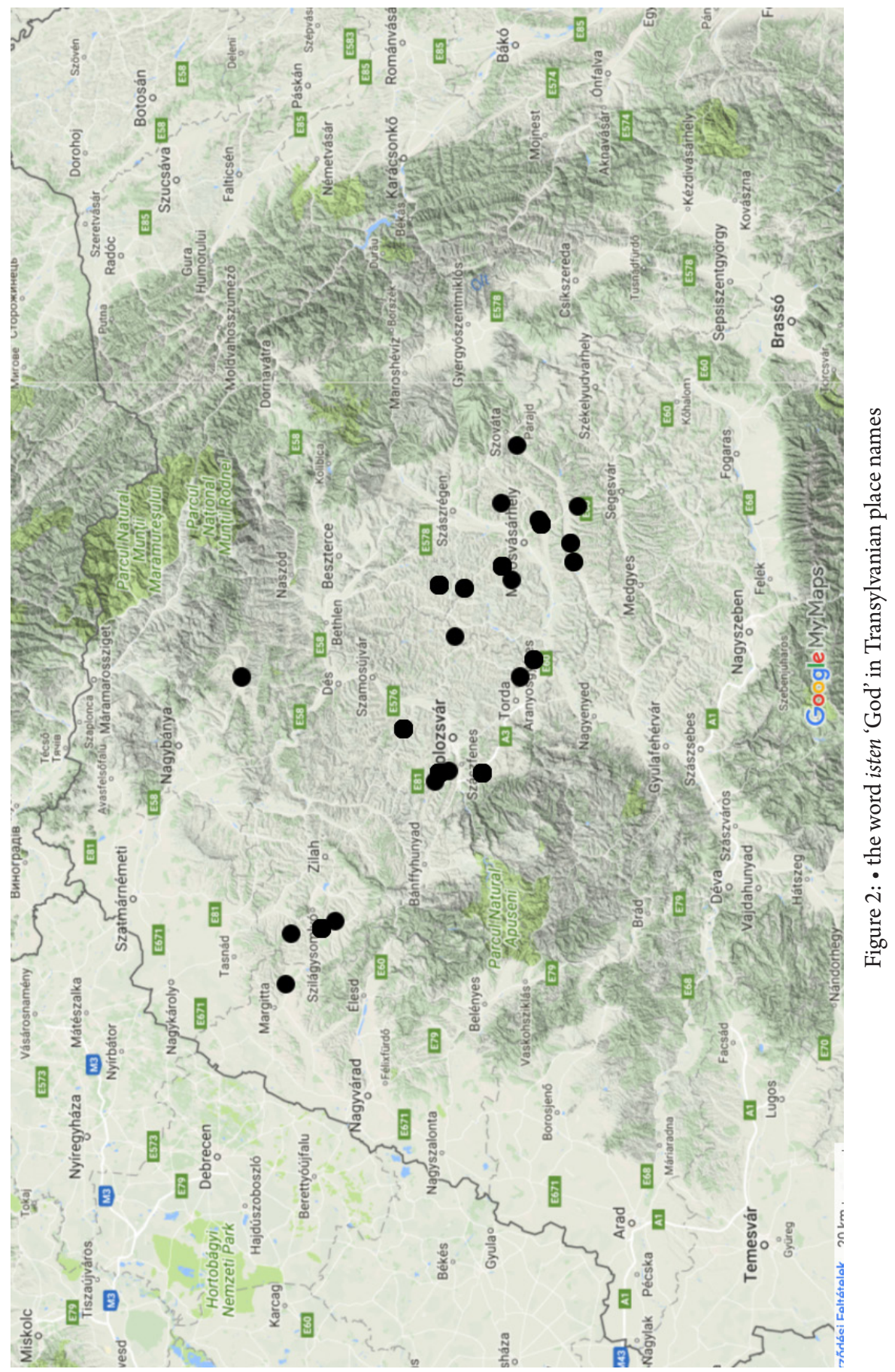




\section{References}

Balassa, I. 1996. Szabó T. Attila (1906-1987). Erdély nagy nyelvtudósa. Budapest.

Balassa, I. and Gy. Ortutay. 1979. Magyar néprajz, 518-519. Budapest.

Bárth, J. M. (ed.) 2006. Emlékkönyv Szabó T. Attila születésének 100.évfordulójára. Budapest.

Bárth, J. M. 2011. Szabó T. Attila Erdélyi történeti helynévgyüjtésének informatizálási munkálatairól. In Hangok - helyek. Tanulmányok dialektológiai adattárak és helynévtárak számítógépes feldolgozásáról, J. M. Bárth and F. S. Vargha (eds.), 11-33. Budapest.

Benő, A. and Cs. T. Szabó (eds.). 2016. Az ember és nyelv - térben és időben. Kolozsvár.

Bölcskei, A., P. Havas and M. Slíz. 2008. A háromszéki Angyalos és Kökös család- és helynevei. Magyar Névtani Dolgozatok 203. Budapest.

eha.elte.hu = Database of Transylvanian Historical Place Names and Interactive Linguistic Map. Based on Attila Szabó T.s collection of place names, edited by János Bárth M.

ETH = Hajdú, M. et. alii. 2001-2010. Szabó T. Attila erdélyi történeti helynévgyüjtése. I-XI. Budapest.

Hoffmann, I. 1993. Helynevek nyelvi elemzése. Debrecen.

Péntek, J. 2006. Az iskolateremtő Szabó T. Attila. Magyar Nyelvjárások 44: 5-12.

Szabó, A. T. 1945. Anygyalhegye és Zanygyalhegye. Erdélyi Múzeum L: 111-112.

Szabó, A. T. 1958. Az „Erdélyi helynévtörténeti adattár” és az erdélyi helynévkutatás néhány kérdése. Magyar Nyelv 54: 503-509.

Thész, D. 2000. Az ördög helyneveinkben. Névtani Értesítő 22: 19-22. 